\title{
The Role of Opinion Leaders in the Sustainable Development of Corporate-Led Consumer Advice Networks: Evidence from a Chinese Travel Content Community
}

\author{
Lianren $\mathrm{Wu}^{1,2} \mathbb{1}$, Jinjie $\mathrm{Li}^{3, *}$, Jiayin $\mathrm{Qi}^{2,4}$, Deli Kong ${ }^{5}$ and $\mathrm{Xu} \mathrm{Li}^{6}$ \\ 1 School of Management, Shanghai University of International Business and Economics, \\ Shanghai 200336, China; lianrenwu@suibe.edu.cn \\ 2 Institute of Artificial Intelligence and Change Management, Shanghai University of International Business \\ and Economics, Shanghai 200336, China; qijiayin@139.com \\ 3 School of Tourism Management, Shanghai Normal University, Shanghai 201418, China \\ 4 Key Laboratory of Trustworthy Distributed Computing and Service, Ministry of Education, \\ Beijing 100086, China \\ 5 School of Business and Management, Shanghai International Studies University, Shanghai 201620, China; \\ lidekong@gmail.com \\ 6 YunlianZhigao (Beijing) Information Technology Research Institute Co., Ltd., Beijing 100086, China; \\ lixubupt@163.com \\ * Correspondence: leejinjie@shnu.edu.cn
}

Citation: Wu, L.; Li, J.; Qi, J.; Kong, D.; Li, X. The Role of Opinion Leaders in the Sustainable Development of Corporate-Led Consumer Advice Networks: Evidence from a Chinese Travel Content Community. Sustainability 2021, 13, 11128. https://doi.org/ $10.3390 /$ su131911128

Academic Editors: Manuel Au-Yong-Oliveira and Maria José Sousa

Received: 23 August 2021

Accepted: 28 September 2021

Published: 8 October 2021

Publisher's Note: MDPI stays neutral with regard to jurisdictional claims in published maps and institutional affiliations.

Copyright: (c) 2021 by the authors. Licensee MDPI, Basel, Switzerland. This article is an open access article distributed under the terms and conditions of the Creative Commons Attribution (CC BY) license (https:/ / creativecommons.org/licenses/by/ $4.0 /)$.

\begin{abstract}
Online community marketing and social media influencer marketing have aroused the interest of many researchers and practitioners around the world. Companies building online content communities to implement community marketing and influencer marketing has become a new corporate strategy, especially in the tourism and hotel industries in which experiential products are sold. However, based on the content community, maintaining the sustainable development of a consumer advice network composed of opinion leaders and consumers is a major challenge. This paper selects the travel content community of Qunar.com as the research object to study the role of opinion leaders in the sustainable development of corporate-led consumer advice networks (CANs). Empirical evidence based on network evolution data from 1356 "Hotel Sleep Testers" across 11 years shows that: (1) the creation and provision of information can obviously increase the probability of the relationship construction and increase the number of relationships, thus facilitating the formation of opinion leadership (OL); (2) active participation in interactions and withhigh-quality information brings greater effects; (3) the network structure variables, such as preferential attachment, structural equivalence, and similarity, can also better predict the probability of a potential relationship; and (4) reciprocity in consumer advice networks has no significant impact on the establishment of network relationships.
\end{abstract}

Keywords: content community; sustainable marketing; SMIs marketing; consumer advice network; opinion leaders; network structure

\section{Introduction}

As market competition intensifies and advertising costs increase, it has become increasingly difficult and expensive for companies to acquire new customers and maintain old customers. Current high-cost and low-efficiency marketing strategies have become unsustainable. In this context, on the one hand, more companies use social media to build online brand and content communities to cultivate potential customers [1-3]; on the other hand, consumers are increasingly using social media to obtain information on which to base their decisions [4].

However, the network formed by corporate-led brand communities and content communities is different from traditional social networks. The formation mechanism and role of opinion leaders in the network are also very different. The sustainable development 
of consumer advice networks composed of opinion leaders and consumers is a major challenge faced by enterprises.

Why do some members of a consumer advice network become influencers (i.e., opinion leaders) while others do not? How should companies cultivate or help the formation of opinion leaders, and what management strategies should be used to maintain the sustainability of the network? These are the management questions that this study will address.

In traditional social networks, online relationships reflect offline social relationships. At the same time, network members know each other in real life and network relationships are built to meet the needs of both social interaction and emotional support $[5,6]$. In such an environment, opinion leaders are formed mainly because of social resources and social status. For examples, opinion leaders in an organization are usually leaders with higher positions. This endogenous factor determines the formation of opinion leaders in social networks and embedded opinion leaders are more stable due to the slow change in social structures [7]. Compared with traditional social networks, the most important feature of consumer advice networks is that the network relationships are separated from real life and the network members are anonymous. More importantly, in consumer advice networks, relationships are not constructed primarily to meet the needs of social interaction but rather to obtain valuable information. Therefore, the relationship is essentially a flow relationship, which represents the flow of information [8]. Many such networks already exist, including online communities created by companies themselves, such as the Xiaomi content community (xiaomi.cn, accessed on 3 March 2010); content communities of travel enterprises (tips.qunar.com, accessed on 2 May 2005); and social commerce platforms, such as Xiaohongshu (xiaohongshu.com, accessed on 1 December 2013), Meilishuo (meilishuo.com, accessed on 1 November 2009), and Mushroom Street (mogu.com, accessed on 1 January 2011). In these networks, network members are usually anonymous and their real-life roles and social resources of network members cannot be brought in.

With the help of various social media platforms, opinion leaders contribute their shopping and life experiences in an anonymous way to communicate with other members. At the same time, consumers actively join such social advice networks to search for the product and service-related information $[9,10]$. Therefore, in consumer advice networks, opinion leaders are actually information-providers. This fully reflects the second dimension of opinion leaders, which is that, in some aspects, opinion leaders should have more expertise. As shown in Table 1, we have compared the characteristics of the two types of networks.

Table 1. Characteristics of the two types of networks.

\begin{tabular}{|c|c|c|}
\hline & Social Networks & Consumer Advice Networks \\
\hline Relationship Type & $\begin{array}{l}\text { Social relationships such as } \\
\text { friends, colleagues, and } \\
\text { relatives }\end{array}$ & $\begin{array}{c}\text { Information flow relationship; } \\
\text { information sharing and } \\
\text { access }\end{array}$ \\
\hline Both sides of the relationship & Acquaintances & Strangers \\
\hline Relationship strength & $\begin{array}{l}\text { Stable relationships; strong } \\
\text { links }\end{array}$ & $\begin{array}{l}\text { Relationships are unstable } \\
\text { and can be built and broken at } \\
\text { any time }\end{array}$ \\
\hline Member needs & $\begin{array}{l}\text { Emotional interaction; } \\
\text { information sharing }\end{array}$ & $\begin{array}{c}\text { Information sharing; product } \\
\text { and service information } \\
\text { acquisition }\end{array}$ \\
\hline Examples & WeChat, QQ, and Facebook & $\begin{array}{c}\text { Xiaohongshu and Mushroom } \\
\text { Street }\end{array}$ \\
\hline
\end{tabular}

Notes: the contents of Table 1 are summarized by the authors.

In traditional social networks, this advisory relationship is through face-to-face conversation or other actual methods of communication [11]. In consumer advice networks, consumers search for reviews of relevant products, as well as opinions from opinion leaders. Therefore, the creation and supply of information represent the value of opinion leaders 
and are the core elements of their formation; only if opinion leaders can provide sufficient, useful information will other members follow them and become their "fans". Theoretically, this reflects the interaction between content and network relationship-establishing; the more content influencers contribute, the more followers will be attracted to establish relationships with them. With more followers, opinion influencers will be more motivated to create content in network nodes $[12,13]$. Therefore, in consumer advice networks, information is the core and the purpose of network members' participation is to obtain useful information. Those members who can provide rich and useful information are more able to attract others' attention and become opinion leaders in the networks [14].

Accordingly, we found that the formation and development of consumer advice networks are likely related to the network structure and influencers (i.e., opinion leaders) in the network. The theoretical goal of this study is to explore the factors influencing the establishment of network relationships among members in consumer advice networks in terms of two dimensions, namely network structure and behavioral activities of opinion leaders, so as to reveal the mechanisms of sustainable development of such networks. In the context of corporate-led consumer advice communities and social media marketing, this study obtains mechanisms for establishing network relationships between opinion leaders and members, bridging the gap in research on the role of opinion leaders in this context.

\section{Literature Review}

\subsection{Influencer Marketing}

The past decade has witnessed a major change in social media marketing characterized by a shift towards social media influencer (SMI) marketing $[15,16]$. The growth of SMI marketing accelerated with the outbreak of COVID-19. During lockdown, people increasingly turned to social media for entertainment and virtual social experiences. Consequently, SMI marketing has become an essential part of digital marketing strategies as a touch-point for reaching target audiences [17-19]. In the increasingly competitive social media environment, influencer marketing is evolving into long-term partnerships between brands and influencers [20,21].

While reviewing the literature on SMIs, we found that much of the prior research leaned towards investigating the relationship between SMIs and their followers from the SMIs' perspective [22,23]. In doing so, one line of research suggested that SMIs are opinion leaders who have the ability to sway their followers' tendency to accept their advice [24,25]. However, another line of research focused on the SMIs' role as taste-makers and described the way their judgment of aesthetic taste influenced their followers' purchase decisions [26,27]. When identifying the SMI phenomenon, one line of research focused solely on SMIs' personal traits, such as authenticity [28], attractiveness [29], and affinity [30]. Another line of research indicated that followers are attracted to the content of SMIs, such as entertaining [31] or informative content [32]. However, the personal traits of SMIs and their ability to curate social media content are equally important in attracting and retaining followers [33].

\subsection{Opinion Leaders and Their Influence}

Opinion leaders play a key role in new product adoption and in the dissemination of relevant information [34], thus it is an essential element in marketing communications [35,36]. Some studies have identified that opinion leaders have a critical influence on social media networks' development [37]. Opinion leaders in social media networks can foster members' interactions, engagement, as well as the reciprocity and transitivity of their followers, which indicates how members form an interactive, cohesive, and equally distributed community [38,39]. However, the mechanism of how opinion leaders expand their interactive networks in social media networks has not yet been discovered [40].

Opinion leaders demonstrate their influence not only on others' opinions but also on others' attitudes and behaviors [41]. Based on the analysis of previous studies, the formation of opinion leaders and their influence are mainly related to their expertise 
in a field, in the involvement in a field, and in social ties [42]. Members' perceived risk and their trust in opinion leaders are also considered to play important roles in the influencing process of opinion leaders' over their followers [43]. The underlying dimensions of opinion leadership have often been assessed using questionnaires, selfreports, and some measurements of opinion leadership, include the ability to persuade your audience.

\section{Hypotheses and Research Model}

In the SMI marketing context, influencers (i.e., opinion leaders) help consumers make purchase decisions through social media. This is mainly reflected through opinion leaders contributing content, interacting with consumers, and answering consumers' questions through social media. Therefore, we hypothesize that the behavioral activities of opinion leaders significantly influence the establishment of network relationships between network members and opinion leaders. We first construct research hypotheses H1, H2, and H3 in terms of the behavioral activities of opinion leaders in consumer advice networks, including content contribution, social interaction, and offering help. In addition to the behavioral activities of opinion leaders, the position of opinion leaders in the network also affects the establishment of network relationships. Therefore, we propose research hypotheses $\mathrm{H} 4$, $\mathrm{H} 5, \mathrm{H} 6$, and $\mathrm{H} 7$ from the perspective of network structure, such as regarding preferential attachment, homophily, structural equivalence, and reciprocity.

\subsection{Content Contribution}

In previous studies on social networks, network nodes are considered as sources of resources or benefits (benefit), which in turn can be utilized by other nodes through the construction of relationships $[44,45]$. For example, if someone is well established in an organization, other members of that organization can potentially take advantage of the resources held by that person by establishing relationships with him. In the case of the consumer advice networks we studied, the benefit of network relationship-establishing concerns the ability to obtain information about products and services from others, helping consumers to eliminate information asymmetry in the purchase process. Therefore, when a consumer considers whether to establish a relationship, he/she makes a decision based on the expectation of the resources that the relationship will bring. In consumer advice networks, this expectation is mainly for information and if the consumer believes that the network relationship will bring him/her rich and valuable information, the consumer is more likely to establish a relationship [46]. In consumer advice networks, opinion leaders gain attention because they become a valuable source of information and use high-quality information to attract these "fans". This interaction between information contribution and network relationship-establishing has been verified by several empirical studies. In general, the more content users post, the more relationships they have with other nodes; in turn, more relationships stimulate the creation of network content $[13,47]$. Furthermore, some members actively contribute content to advice networks without being paid for it because some people experience pleasure from this content-sharing behavior; in addition, this content-sharing behavior increases their reputation and influence in the community [48].

It can be seen that the content contributed by the influencer is an important factor that attracts others' attention, thus we propose hypothesis H1.

Hypothesis 1 (H1). The more content a member contributes, the more other members will establish a relationship with him/her and the more likely he/she is to become an opinion leader.

\subsection{Interaction}

Interaction also plays a key role in developing virtual social networks where communications take place thorough computers or devices [49]. Online social interaction propensity is defined as the general tendency of a member to interact in an online environment with people they have not met in person. Blazevic et al. noted that it is an individual trait 
that differentiates individuals with regard to their predisposition to interact with others on online communities [50]. Therefore, members of these communities can be classified according to their presence (posters) or lack of willingness (lurkers) to engage in online interactions with others on these platforms [51]. Wiertz et al. showed that if customers are prone to interact online, they tend to make more insightful contributions, thus this variable is a crucial attribute in relation to online community members' participative behavior [52]. Dessart showed a positive relationship between online interaction propensity and some behaviors [53]. Therefore, online interaction propensity may strengthen the influence of opinion leadership on those variables that involve online communication [54]. In summary, we propose hypothesis $\mathrm{H} 2$.

Hypothesis 2 (H2). The more actively a member interacts online, the more other members will establish a relationship with him/her and the more likely he/she is to become an opinion leader.

\subsection{Helpfulness}

The helpfulness of online reviews has been a hot topic in social e-commerce [55] and marketing research over the past decade [56]. The research is mainly concerned with the prediction of review helpfulness [57], the determinants of review helpfulness [58], and the measurement of review helpfulness [59]. For example, Huang et al. examined the effect of message length together with aspects of review patterns and reviewer characteristics on review helpfulness [60]. Qazi et al. explained why some reviews are more helpful compared to others [61].

We found in the literature that the helpfulness of online reviews is closely related to the quality of it. Meanwhile, the quality of reviews has been regarded as important in constructing a reputation in a community, which in turn may lead the user to be considered as an opinion leader [62]. Some characteristics of the shared content, such as the attractiveness, quality, and composition of the images, are crucial for users to make the decision to follow a specific profile [63]. Other aspects related to quality, such as the comprehensiveness of the content [12], assertiveness, and emotion [64], have also been shown to be drivers of opinion leadership.

Bearing all these in mind, it is proposed that the helpfulness of the content contributed by social media influencers will influence the perception of opinion leadership. We propose hypothesis $\mathrm{H} 3$.

Hypothesis 3 (H3). The more helpful content a member contributes, the more other members will establish a relationship with him/her and the more likely he/she is to become an opinion leader.

\subsection{Preferential Attachment}

Preferential attachment describes a social network in which network nodes with more relationships are more attractive to other nodes, similar to "the stronger the stronger, the weaker the weaker" concept. This phenomenon has been confirmed in many different networks such as scholar collaboration networks, Internet sites, etc. [65]. The main reason for this phenomenon is that network nodes search for star nodes in the network when establishing relationships and the value of establishing relationships with such star nodes is higher than the value of establishing relationships with ordinary nodes for judging star nodes [66]. In combination with the formation of opinion leaders, this phenomenon of preferential attachment seems to be more prevalent [67]. Therefore, we propose hypothesis H4.

Hypothesis 4 (H4). The more followers a member has, the more other members will establish a relationship with him/her and the more likely he/she is to become an opinion leader. 


\subsection{Homophily}

Homophily refers to the perceived similarity in beliefs, values, experiences, and lifestyles of the communicator by the receiver [68]. Communicators with affinity tend to be influential and can greatly affect recommendations [69]. Perceived similarity creates positive intergroup emotions and reduces uncertainty [70]. In such a situation, a listener is likely to infer that the communicator's attitude, interests, beliefs, and emotions are similar to their own, resulting in the listener endorsing the opinion.

Social network members, being in similar network locations, generate similarity in different dimensions, such as through behaviors and perceptions [71]; additionally, this similarity leads to trust among members and it is often easier to interact and establish relationships among similar network members [72]. For example, Centola found that homophily significantly increased the overall adoption of new health behavior [73]. Ma found that the latent homophily effect has a significant impact on product choice decisions of consumers [74]. Therefore, we propose hypothesis H5.

Hypothesis 5 (H5). In consumer advice networks, homophily positively affects the establishment of network relationships.

\subsection{Structural Equivalence}

The concept of structural equivalence describes the similarity of two network nodes in terms of network structure, specifically the common network nodes to which the two nodes are connected to [75]. The structural equivalence reflects the network closure feature of the network structure, that is, the network nodes are closely connected to each other. Such a network structure not only facilitates the dissemination of information but also promotes the formation of trust and the establishment of relationships in the network [76]. Therefore, we propose hypothesis H6.

Hypothesis 6 (H6). In consumer advice networks, structural equivalence positively affects the establishment of network relationships.

\subsection{Reciprocity}

Reciprocity is one of the basic principles of social relations $[77,78]$. The concept of reciprocity derives from social exchange theory. Reciprocity is regarded as the mechanism of social exchange [79]. Constant et al. (1994) argued that when two individuals are influenced by their social and organizational environment, the social exchange relationship will be the main determinant of their attitudes [80]. Huber also argued that based on people's desire for fairness and reciprocity, members in a society believe their mutual relationships with one another will improve [81]. This implies that when members in virtual social networks have a higher level of reciprocity, their awareness and evaluation of the relationships with other members in that network are more positive. For example, Xiong et al. argued that members' reciprocity positively affects their knowledge contribution and establishment of social relationships in virtual social networks [82].

Therefore, we introduce reciprocity as another social perspective to analyze formation mechanisms of opinion leaders in consumer advice networks. We propose hypothesis H7.

Hypothesis 7 (H7). In consumer advice networks, reciprocity positively affects the establishment of network relationships.

Based on the above hypotheses, the proposed model is summarized in Figure 1. 


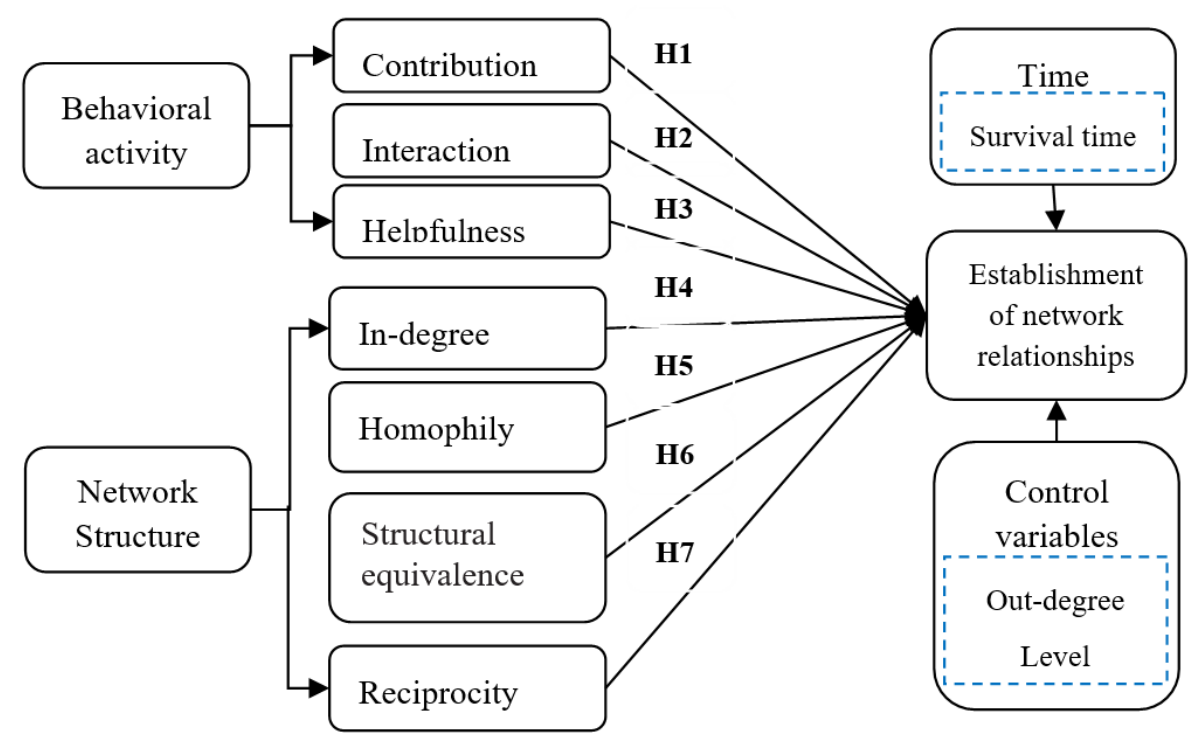

Figure 1. Research model.

\section{Research Design}

\subsection{Data Source}

In order to test the hypotheses proposed in this paper, we selected the content community of the "Qunar Travel" website (http:/ / tips.qunar.com/, accessed on 2 May 2005) as the research object [83]. This content community is a typical consumer advice network.

Qunar Travel (https:/ / www.qunar.com/, accessed on 2 May 2005) is one of the larger Chinese online travel websites, founded in February 2005 and headquartered in Beijing. Qunar provides consumers with real-time searches for airline tickets, hotels, venues, and vacation products, as well as group purchase options for travel products and other travel information services.

The content community of "Qunar Travel" allows registered members of the site to post a variety of reviews about hotel products and service experiences anonymously in the community. Members of the site can follow other members and can be followed by other members. Following gives them priority to see the reviews posted by the followed members and these reviews help potential consumers in their purchasing decisions. For this reason, we refer to such communities as online consumer advice networks.

\subsection{Data Collection}

To study the mechanisms of opinion leadership formation among influencers in consumer advice networks, we selected certified members of the network who had the "sleep tester" logo (shown in Figure 2). Both certified and uncertified members exist in consumer advice networks and allow for both relationship-establishing and social interaction between them.

"Hotel sleep testers", also known as the "hotel connoisseur", require candidates to have a keen sense of observation and feeling, a love of travel, and a willingness to share what they see and hear. The creation of hotel sleep testers has its own theoretical basis and review-based marketing has become an effective marketing approach that is widely used with good results. Research shows that $90 \%$ of hotel online booking users view and refer to other people's hotel reviews. As a result, a large number of objective reviews on online travel sites can often attract consumers to book hotels through suppliers. 


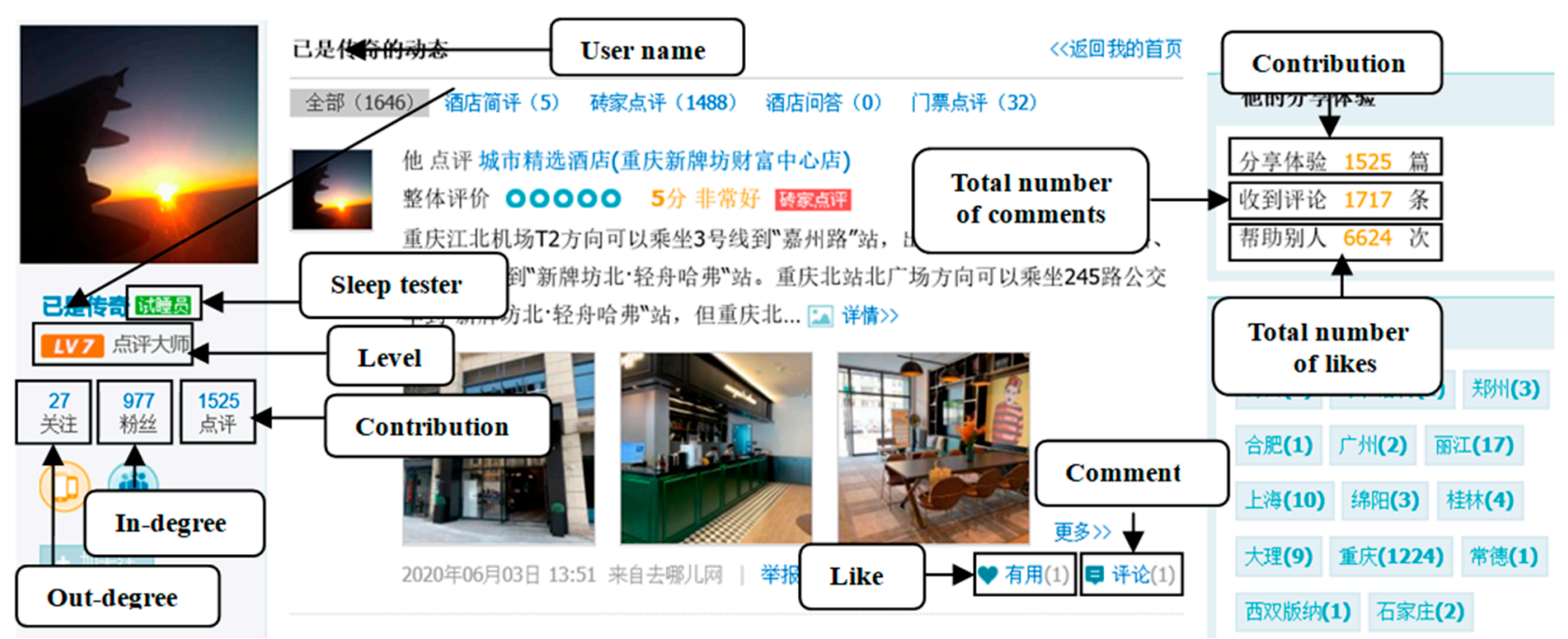

Figure 2. Schematic diagram of hotel sleep testers' homepage.

To be certified as a "Hotel Sleep Tester", one must first apply and go through a rigorous vetting process. As such, "Hotel Sleep Testers" are a group of influencers who want to influence others, have a willingness to share what they see and hear, and aim to become opinion leaders. This study will explore which "Hotel Sleep Testers" are able to become opinion leaders and why.

We needed to select some "Hotel Sleep Testers" and observe the establishment of network relationship among them. First, eight "Hotel Sleep Testers" were randomly selected; second, 1356 "Hotel Sleep Testers" were selected from the consumer advice network (tips.qunar.com, accessed on 2 May 2005) using the snowball method; and third, the relationship establishing data, behavioral activity data, and other data of these 1356 "Hotel Sleep Testers" were obtained.

The data records of the network members date back to as early as December 2009, with a time span of 11 years of data to December 2020. The time-series data with a long time span provides us with rich data points for analyzing relationship-establishing patterns and also ensures the robustness of our findings, which is crucial for studying the formation of social network relationships.

\subsection{Variable Construction}

Due to the long time span of the data, we set the interval between each observation to a quarter and constructed a panel data in quarterly time intervals. The dependent variable in this study is the state of relationship establishment, which takes the value of 0 if the relationship is not established at the moment of observation and 1 if the relationship is established.

For the convenience of representation, the following assumption is made: denote the network formed by members by $G(V, E)$, where $V$ is the set of network nodes (i.e., members) and $E$ is the set of network edges (i.e., relations). Next, we considered whether a potential edge (relationship) $E_{i j}=\left(V_{i}, V_{j}\right)$ is established, with $E_{i j}$ denoting $V_{i}$ as the following node (fan) and $V_{j}$ as the followed node (influencer). The specific independent and control variables are defined as shown in Table 2. 
Table 2. Variable explanation.

\begin{tabular}{|c|c|c|}
\hline & Variable & Calculation Method \\
\hline $\begin{array}{l}\text { Dependent } \\
\text { variable }\end{array}$ & $\begin{array}{l}\text { Relationship } \\
\text { establishment }\end{array}$ & $\begin{array}{l}\text { If the potential relationship } E_{i j} \text { is not established at time } \\
t \text {, it takes the value } 0 \text {; otherwise, it takes the value } 1 .\end{array}$ \\
\hline \multirow{3}{*}{$\begin{array}{l}\text { Independent } \\
\text { variables }\end{array}$} & Contribution & The number of comments contributed by $V_{j}$ at time $t$. \\
\hline & Interaction & The total number of comments received by $V_{j}$ at time $t$. \\
\hline & Helpfulness & The total number of likes obtained by $V_{j}$ at time $t$. \\
\hline \multirow{4}{*}{$\begin{array}{l}\text { Independent } \\
\text { variables }\end{array}$} & In-degree & Number of followers of $V_{j}$ at time $t$. \\
\hline & $\begin{array}{c}\text { Structural } \\
\text { equivalence }\end{array}$ & $\begin{array}{l}\text { Number of nodes that establish relationships with both } \\
\qquad V_{i} \text { and } V_{j} \text { at time } t \text {. }\end{array}$ \\
\hline & Homophily & $\begin{array}{l}\text { The absolute value of the difference between the level of } \\
\qquad V_{i} \text { and } V_{j} \text { at time } t .\end{array}$ \\
\hline & Reciprocity & $\begin{array}{c}\text { At time } t \text {, the value is } 1 \text { if } V_{j} \text { is a follower of } V_{i} ; \\
\text { otherwise, the value is } 0 .\end{array}$ \\
\hline \multirow{3}{*}{ Control variables } & Out-degree & The number of other members that $V_{j}$ follows at time $t$. \\
\hline & Level & The level of $V_{j}$ at time $t$. \\
\hline & Survival time & $\begin{array}{l}\text { The duration member } V_{j} \text { has been in the network, } \\
\text { expressed as the length of time between the moment of } \\
\text { registration and December 2020, in months. }\end{array}$ \\
\hline
\end{tabular}

Furthermore, the measurement of the variables is explained through the personal homepage of a "hotel sleep tester" (as in Figure 2).

Contribution: the number of content posts contributed by the following node $V_{j}$, as shown in Figure 2 "Contribution", is 1525.

Interaction: Other members will have social interaction with the followed member $V_{j}$, which is mainly reflected in the comments on the content posts contributed by $V_{j}$, as shown in the "comment" in Figure 2. The value of interaction is the total number of comments received by member $V_{j}$. As shown in Figure 2, the "Total number of comments" is 1717.

Helpfulness: If other members feel that the content contributed by $V_{j}$ is helpful, they will like the content, such as through the "Like" function in Figure 2. The value of helpfulness is the total number of likes obtained by member $V_{j}$. As shown in Figure 2, the "Total number of likes" is 6624 .

In-degree: Member $V_{j}$ has a number of fans. As shown in Figure 2, the "In-degree" is 977. Structural equivalence: this refers to the number of members that establish relationships with both $V_{i}$ and $V_{j}$, in which the larger the value, the stronger the structural equivalence.

Homophily: the absolute value of the difference between the level of $V_{i}$ and $V_{j}$, in which the smaller the value, the higher the homophily.

Reciprocity: if $V_{j}$ is a follower of $V_{i}$, the value is 1 and otherwise the value is 0 .

Out-degree: The number of members followed by member $V_{j}$. As shown in Figure 2, the "Out-degree" is 27.

Level: The level of member $V_{j}$. As shown in Figure 2, the "Level" is 7.

Survival time: the duration member $V_{j}$ has been in the consumer advice network, expressed as the length of time between the moment of registration and December 2020, in months.

\subsection{Data Analysis}

In this section, we used the software IBM SPSS 21.0 to process the collected data, including descriptive statistics and a correlation analysis, as well as the regression analysis in Section 5 . Table 3 shows the descriptive statistics with data sample $n=1356$. Table 4 shows the results of the correlation analysis between variables with the number of variables $\mathrm{v}=10$. 
Table 3. Descriptive statistics.

\begin{tabular}{cccccc}
\hline No. & Variable & Mean & Max & Min & SD \\
\hline 1 & Contribution & 227.94 & 1524 & 7 & 242.27 \\
2 & Interaction & 315.88 & 1810 & 8 & 338.26 \\
3 & Helpfulness & 721.07 & 6624 & 23 & 944.89 \\
4 & In-degree & 425.04 & 2680 & 56 & 565.81 \\
5 & Structural equivalence & 1.62 & 7 & 0 & 1.89 \\
6 & Homophily & 1.86 & 6 & 0 & 1.32 \\
7 & Reciprocity & 0.43 & 1 & 0 & 0.50 \\
8 & Out-degree & 122.25 & 1000 & 1 & 191.17 \\
9 & Level & 6.42 & 7 & 4 & 0.77 \\
10 & Survival time & 86.56 & 132 & 23 & 30.76 \\
\hline
\end{tabular}

Notes: Sample $n=1356$.The data analysis was conducted using IBM SPSS 21.0 software.

Table 4. Correlations between all the variables.

\begin{tabular}{|c|c|c|c|c|c|c|c|c|c|c|c|}
\hline No. & Variable & 1 & 2 & 3 & 4 & 5 & 6 & 7 & 8 & 9 & 10 \\
\hline 1 & Level & 1 & & & & & & & & & \\
\hline 2 & Out-degree & $-\underset{* *}{0.386}$ & 1 & & & & & & & & \\
\hline 3 & In-degree & 0.059 & -0.008 & 1 & & & & & & & \\
\hline 4 & Contribution & $0.472 * *$ & -0.167 & 0.371 ** & 1 & & & & & & \\
\hline 5 & Interaction & $0.441^{* *}$ & -0.196 & $0.535^{* *}$ & $0.841 * *$ & 1 & & & & & \\
\hline 6 & Helpfulness & $0.390 * *$ & -0.169 & $0.453 * *$ & $0.859^{* *}$ & 0.912 ** & 1 & & & & \\
\hline 7 & Homophily & 0.119 & 0.079 & -0.007 & 0.057 & 0.013 & -0.063 & 1 & & & \\
\hline 8 & $\begin{array}{l}\text { Structural } \\
\text { equivalence }\end{array}$ & -0.027 & -0.103 & -0.210 * & $-0.228 *$ & $\underset{* *}{-0.264}$ & $-0.207^{*}$ & -0.110 & 1 & & \\
\hline 9 & Reciprocity & 0.017 & $-0.202 *$ & 0.102 & -0.054 & -0.048 & -0.030 & $-0.387^{*}$ & $0.427^{* *}$ & 1 & \\
\hline 10 & Survival time & 0.047 & -0.075 & $0.474^{* *}$ & $0.275^{* *}$ & $0.458^{* *}$ & 0.394 ** & -0.051 & -0.055 & -0.047 & 1 \\
\hline
\end{tabular}

Notes: Sample $n=1356,{ }^{*} p<0.05,{ }^{* *} p<0.01$, and ${ }^{* * *} p<0.001$. The data analysis was conducted using IBM SPSS 21.0 software.

\section{Empirical Analysis}

\subsection{Model}

Since we wanted to study whether the potential relationship is established and whether the independent variables are constantly changing over time, it was difficult to apply traditional linear and logit models, thus we mainly used the survival model here.

Survival analysis was originally used mainly in biomedical research, focusing on the duration of a particular event, which in this paper refers to the establishment of network relationships. Due to its superiority in addressing temporal variables, this model has since been widely used in other fields such as criminology, economics, sociology, etc. Survival analysis is also widely used in the field of marketing, mostly to analyze consumer decisions and product diffusion $[84,85]$. One of the more widely used models in survival analysis is the Cox Proportional Hazard Model (Cox PHM) and this paper also focuses on this model form. The model is as follows in Equation (1):

$$
h_{i}\left(t, X_{i}\right)=h_{0}(t) \times \exp \left(\beta X_{i t}\right)
$$

Here, $h_{i}\left(t, X_{i}\right)$ represents the conditional probability that the event of study object $i$ does not occur at time $t-1$ but occurs at time $t . h_{0}(t)$ represents the baseline probability that the event occurs at time $t$, similar to the constant term in a linear model. $X_{i t}$ represents the vector of covariates affecting the magnitude of the probability of event occurrence, which in this paper mainly refers to user behavior, network structure, and control variables. $\beta$ is the parameter to be estimated corresponding to the covariates. $\exp \left(\beta X_{i t}\right)$ represents the effect of variables on the probability of event occurrence. If the value is greater than 1 , it means that the variables will increase the probability of event occurrence. If the value is less than 1, it means that the variables will decrease the probability of event occurrence. 


\subsection{Relationship Establishment}

In order to show the formation process of the relationship in the consumer advice network more intuitively, we present the evolution of the entire network through a network diagram. We divided the evolution of the network into four stages, starting from the initial stage of network establishment (December 2010) and then presenting it every three years. Although this is only a rough display, some simple conclusions can be drawn from Figure 3 (only nodes with an in-degree greater than 10 are shown): firstly, the network shows a dynamic change process as new nodes continue to join the network and new relationships are formed; and secondly, the formation of network relationships is extremely heterogeneous, with some nodes establishing more relationships and others very few.
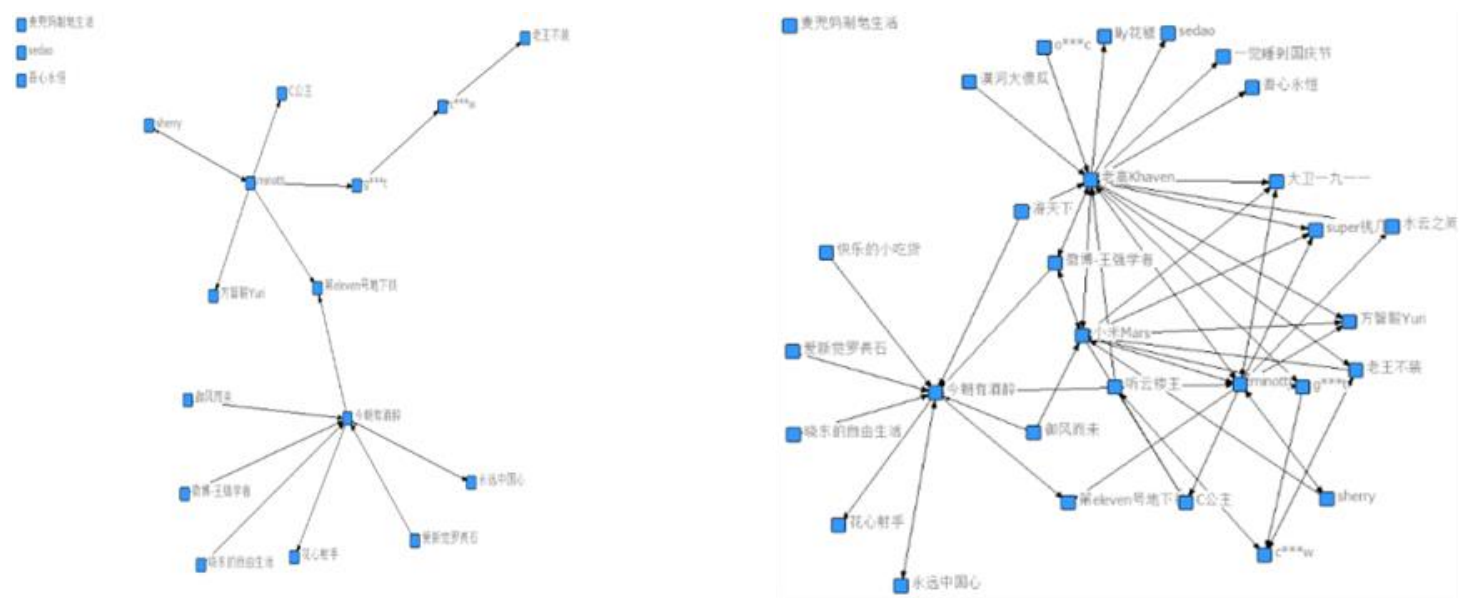

Dec. 2010

Dec. 2013
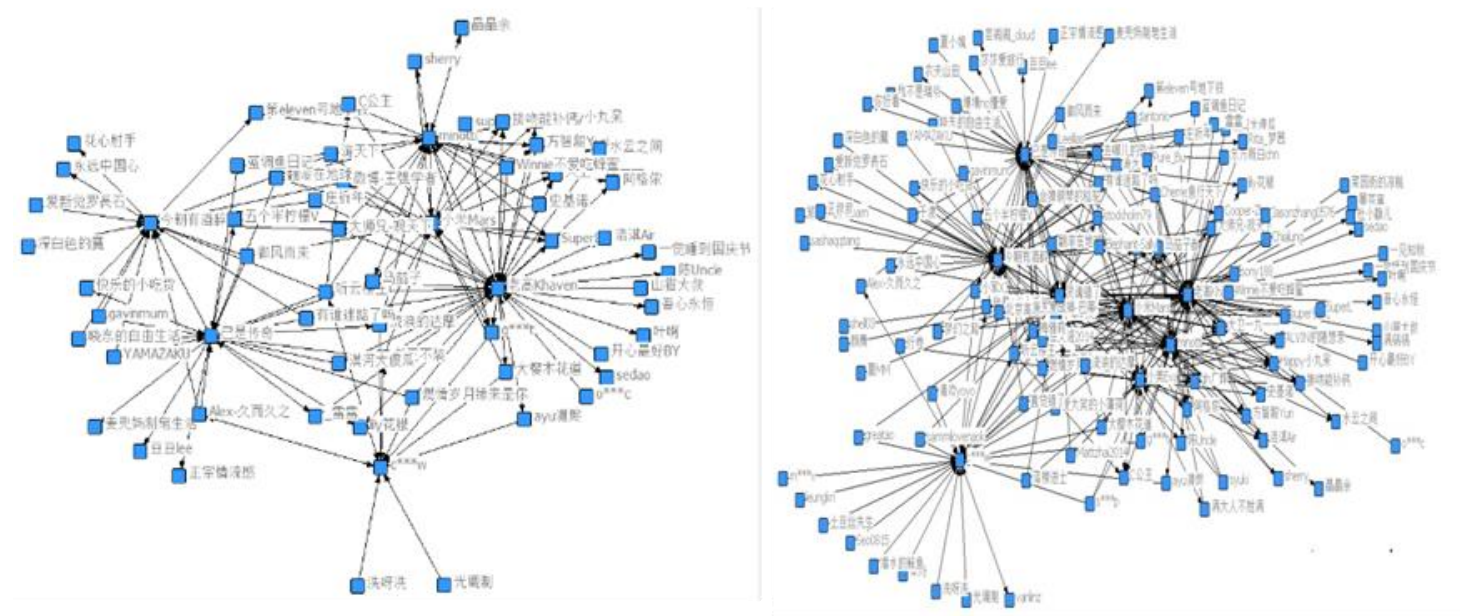

Dec. 2016

Dec. 2020

Figure 3. Evolution of consumer advice network.

We also conducted frequency statistics on the in-degree of network members. Figure 4 shows the frequency distribution. We found that most members have less than 10 relationships and fewer members have more than 1000 relationships. Therefore, only a few members established a large number of relationships and became opinion leaders in the consumer advice network. Our research question asks why these members become opinion leaders. 


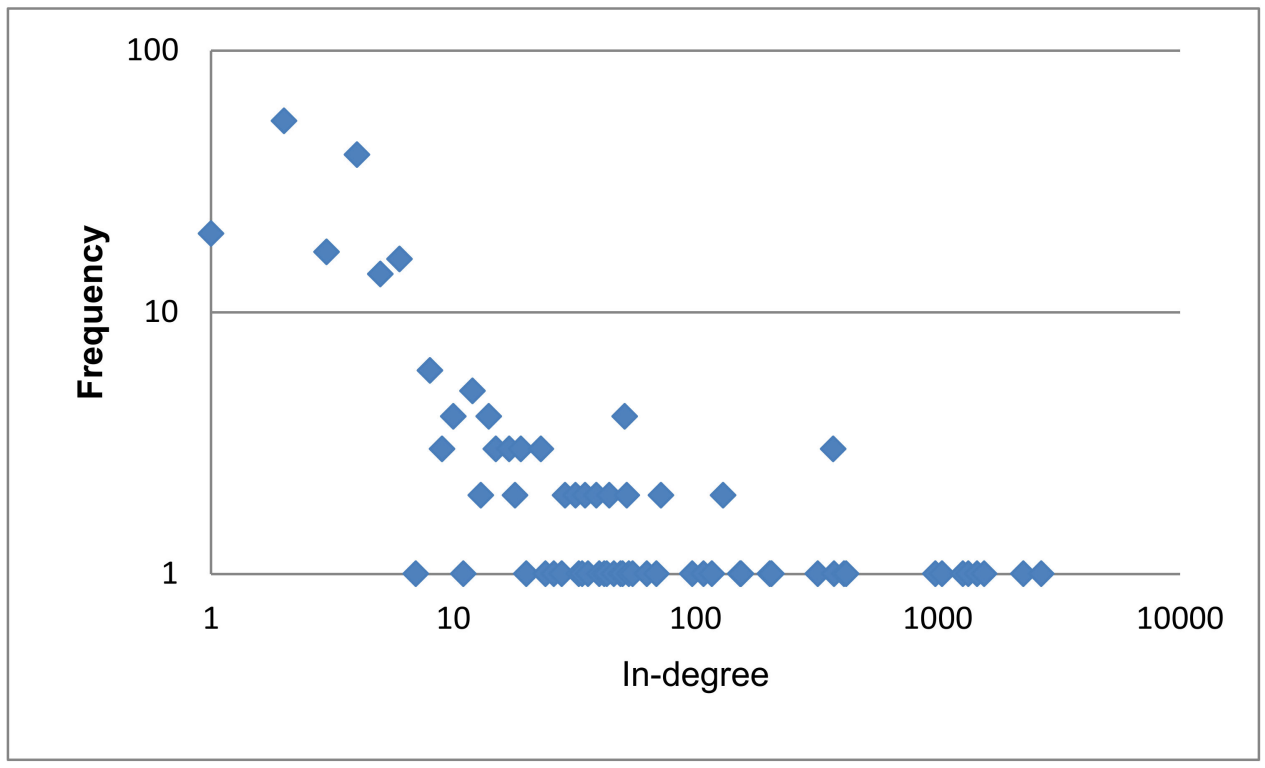

Figure 4. Frequency distribution of the in-degree.

\subsection{Regression Analysis}

This paper uses IBM SPSS Statistics software (version 21) to estimate the coefficients of each variable using the "analysis-survival function-Cox regression" path. The main coefficients were estimated as shown in Table 5.

Table 5. Coefficient estimation.

\begin{tabular}{|c|c|c|c|c|c|c|c|}
\hline & \multirow{2}{*}{ Variables } & \multicolumn{2}{|c|}{ Model 1} & \multicolumn{2}{|c|}{ Model 2} & \multicolumn{2}{|c|}{ Model 3} \\
\hline & & Coefficient & Hazard Rate & Coefficient & Hazard Rate & Coefficient & Hazard Rate \\
\hline \multirow{3}{*}{$\begin{array}{l}\text { Behavioral } \\
\text { activity }\end{array}$} & Contribution & $0.090^{* * *}$ & 1.094 & $0.050 * * *$ & 1.051 & $0.050 * * *$ & 1.051 \\
\hline & Interaction & & & $0.060^{* * *}$ & 1.062 & $0.054^{* * *}$ & 1.055 \\
\hline & Helpfulness & & & $0.020 * *$ & 1.020 & $0.020^{* * *}$ & 1.020 \\
\hline \multirow{5}{*}{ Networkstructure } & In-degree & $0.170 * *$ & 1.017 & $0.190 * *$ & 1.019 & $0.107^{* *}$ & 1.113 \\
\hline & In-degree $^{2}$ & $0.000^{* * *}$ & 1.000 & $-0.002^{* * *}$ & 0.998 & $-0.002 * * *$ & 0.998 \\
\hline & $\begin{array}{c}\text { Structural } \\
\text { equivalence }\end{array}$ & $0.941^{* *}$ & 2.562 & $0.471^{* *}$ & 1.602 & $0.326^{* *}$ & 1.385 \\
\hline & Homophily & $0.150^{* *}$ & 0.985 & $0.122^{* *}$ & 1.129 & $0.145^{* *}$ & 1.156 \\
\hline & Reciprocity & 0.070 & 1.073 & 0.065 & 1.067 & 0.060 & 1.062 \\
\hline \multirow{2}{*}{ Controlvariables } & Out-degree & & & & & 0.002 & 1.002 \\
\hline & Level & & & & & 0.319 & 1.376 \\
\hline
\end{tabular}

Notes: Sample $n=1356,{ }^{*} p<0.05,{ }^{* *} p<0.01$, and ${ }^{* * *} p<0.001$. The data analysis was conducted using IBM SPSS 21.0 software.

In Model 1, we first considered the effect of content contribution. From the regression results, it can be seen that the content contribution is positively correlated with the establishment of the relationship $(\mathrm{B}=0.090, p<0.001)$. That is, hypothesis $\mathrm{H} 1$, "The more content a member contributes, the more other members will establish a relationship with him/her and the more likely he/she is to become an opinion leader", is supported.

From the perspective of network structure, the establishment of a relationship has the characteristics of preferential attachment $(\mathrm{B}=0.170, p<0.001)$. That is, hypothesis $\mathrm{H} 4$, "The more followers a member has, the more other members will establish a relationship with him/her and the more likely he/she is to become an opinion leader", is supported. 
However, when the number of fans (in-degree) is squared, the coefficient becomes 0 , which shows that this effect is not linear but rather diminishes the margin.

In addition, the homophily among members also has a positive impact on the establishment of relationships $(\mathrm{B}=0.150, p<0.01)$. Therefore, hypothesis H5, "In consumer advice networks, homophily positively affects the establishment of network relationships", is supported.

From the perspective of relationship norms, the stronger the structural equivalence between members, the more likely it is to establish relationships, which reflects the role of overlap in network structures in promoting the establishment of network relationships ( $\mathrm{B}=0.941, p<0.01)$. Additionally, its effect is far greater than that of other factors. That is, hypothesis $\mathrm{H6}$, "In consumer advice networks, structural equivalence positively affects the establishment of network relationships", is supported.

Hypotheses $\mathrm{H} 4, \mathrm{H} 5$, and $\mathrm{H} 6$ are consistent with the findings of previous studies. In traditional social networks, collaborative networks, and offline networks, preferential attachment mechanisms [86], structural equivalence [87], and homophily [88-90] play very important roles in the establishment of network relationships, in the development of cooperation, and in the formation of alliances.

However, hypothesis H7, "In consumer advice networks, reciprocity positively affects the establishment of network relationships", is not supported in this study. This conclusion is different from acquaintance social networks. In traditional acquaintance social networks, reciprocity has a strong positive impact on the establishment of network relationships. The reason is that in the consumer advisory network, members mainly engage in information acquisition and exchange. Members pay attention to opinion leaders but they do not draw the attention of opinion leaders to them. This shows that the exchange of information does not have the feature of reciprocity.

In Model 2, we further discussed the influence of behavioral activities on the establishment of relationships. The social interaction of members in the network has a positive effect on the establishment of relationships ( $\mathrm{B}=0.060, p<0.001)$. Therefore, Hypothesis $\mathrm{H} 2$,"The more actively a member interacts online, the more other members will establish a relationship with him/her and the more likely he/she is to become an opinion leader", is supported. In addition, the total helpfulness of the content contributed by influencers has a positive effect on the establishment of relationships ( $\mathrm{B}=0.020, p<0.005)$. Hypothesis $\mathrm{H} 3$, "The more helpful content a member contributes, the more other members will establish a relationship with him/her and the more likely he/she is to become an opinion leader", is supported.

The results of hypothesis $\mathrm{H} 2$ and hypothesis $\mathrm{H} 3$ were consistent with the results of previous studies. For example, Li suggested that in social blogs with word-of-mouth (WoM) marketing, an opinion leader, who is normally more interconnected and has a higher social standing, can deliver product information, provide recommendations, give personal comments, and supplement professional knowledge, which helps companies to promote their products [42].

In Model 3, we tested the robustness of the above analytical results by including the control variables in the regression model. The results from model 3 show that the conclusions obtained in model 1 and model 2 are valid in model 3 , thus the results of the model are robust.

\subsection{Comparative Analysis}

To further explore the relationship between influencers' online behavioral activities, the network structure, and opinion leader formation, a comparative analysis of opinion leaders and non-opinion leaders was conducted.

Firstly, the influencers in consumer advice networks were classified according to the criteria proposed by the existing literature. Regarding the classification of opinion leaders in social networks, Trusov et al. stated that the top $20 \%$ of influential network nodes in the network are opinion leaders [91], while Goldenberg et al. classified them based on the degree criterion. In this study, the influencers who ranked in the top $20 \%$ in terms of 
the number of followers (i.e., in-degree) were set as opinion leaders [92]. Table 6 shows the mean values of variables and Figure 5 shows the results of the comparison between opinion leaders and non-opinion leaders.

Table 6. Mean value of each variable.

\begin{tabular}{|c|c|c|c|c|c|c|c|c|}
\hline & & Level & SurvivalTime & $\begin{array}{c}\text { Out- } \\
\text { Degree }\end{array}$ & In-Degree & Contribution & Interaction & Helpfulness \\
\hline $\begin{array}{l}\text { Opinion } \\
\text { leaders }\end{array}$ & Mean & 6.60 & 102.11 & 98.25 & 1392.85 & 421.85 & 692.90 & 1610.20 \\
\hline $\begin{array}{l}\text { Non-opinion } \\
\text { leaders }\end{array}$ & Mean & 6.38 & 78.45 & 128.25 & 183.09 & 179.46 & 221.63 & 498.79 \\
\hline ANOVA & & $\begin{array}{l}\mathrm{F}=1.379 \\
p=0.243\end{array}$ & $\begin{array}{c}\mathrm{F}=61.721 \\
p<0.001\end{array}$ & $\begin{array}{l}\mathrm{F}=0.392 \\
p=0.533\end{array}$ & $\begin{array}{c}\mathrm{F}=277.217 \\
p<0.001\end{array}$ & $\begin{array}{c}\mathrm{F}=18.914 \\
p<0.001\end{array}$ & $\begin{array}{c}\mathrm{F}=44.796 \\
p<0.001\end{array}$ & $\begin{array}{c}\mathrm{F}=28.224 \\
p<0.001\end{array}$ \\
\hline \multirow{4}{*}{ Overall } & Mean & 6.42 & 83.76 & 122.25 & 425.04 & 227.94 & 315.88 & 721.07 \\
\hline & $\operatorname{Max}$ & 7.00 & 132.00 & 1000.00 & 2680.00 & 1524.00 & 1810.00 & 6624.00 \\
\hline & Min & 4.00 & 34.00 & 1.00 & 56.00 & 7.00 & 8.00 & 23.00 \\
\hline & $\mathrm{SD}$ & 0.77 & 18.52 & 191.17 & 565.81 & 242.27 & 338.26 & 944.89 \\
\hline
\end{tabular}

Notes: the analysis of variance was done by IBM SPSS 21.0 software.

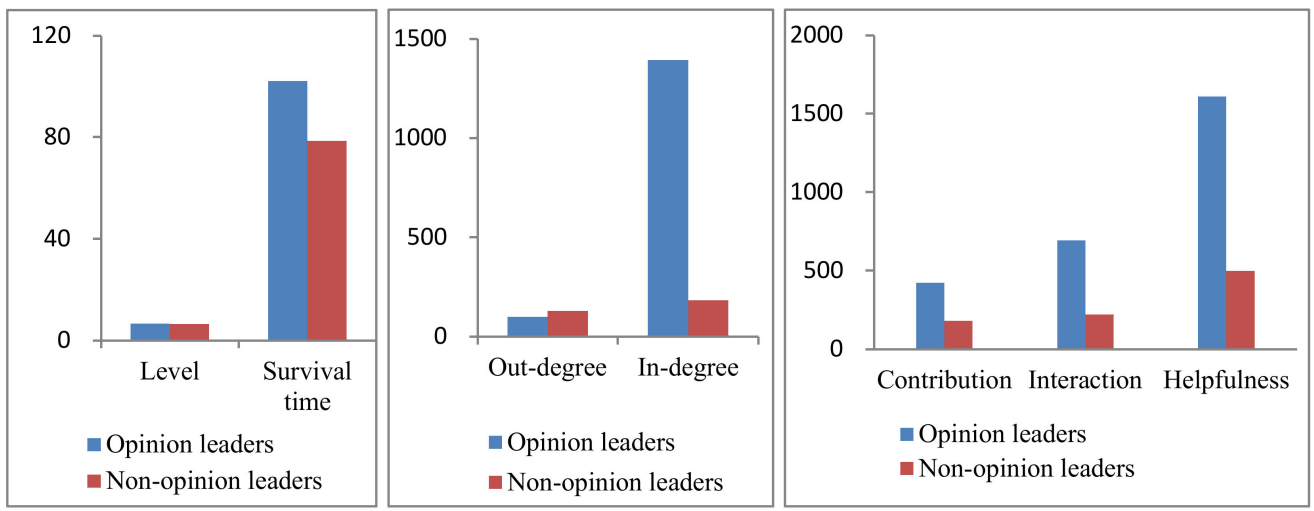

Figure 5. Comparison between opinion leaders and non-opinion leaders.

As seen in Figure 5, there are differences in the behavioral activities and network structure between opinion leaders and non-opinion leaders; however, are there statistically significant differences? To answer this question, we used IBM SPSS Statistics software (version 21) to perform an analysis of variance on the two groups. In terms of the level, there was no significant difference between opinion leaders $\left(\mathrm{M}_{\mathrm{OL}}=6.60\right)$ and non-opinion leaders $\left(\mathrm{M}_{\mathrm{N}-\mathrm{OL}}=6.38 ; \mathrm{F}=1.379, p=0.243\right)$. However, there was a significant difference in the survival time of the two groups $\left(\mathrm{M}_{\mathrm{OL}}=102.11, \mathrm{M}_{\mathrm{N}-\mathrm{OL}}=78.45 ; \mathrm{F}=61.721, p<0.001\right)$. From the regression analysis, we found that level and survival time did not affect the establishment of the relationship. However, the above results show that the survival time of opinion leaders was significantly longer than that of non-opinion leaders.

In terms of the out-degree, there was no significant difference between opinion leaders $\left(\mathrm{M}_{\mathrm{OL}}=98.25\right)$ and non-opinion leaders $\left(\mathrm{M}_{\mathrm{N}-\mathrm{OL}}=128.25 ; \mathrm{F}=0.392, p=0.533\right)$. There was a significant difference in the number of fans (i.e., in-degree) between the two groups $\left(\mathrm{M}_{\mathrm{OL}}=1392.85, \mathrm{M}_{\mathrm{N}-\mathrm{OL}}=183.09 ; \mathrm{F}=277.217, p<0.001\right)$.

In terms of behavioral activities, there was a significant difference in the amount of content contributed by the two groups $\left(\mathrm{M}_{\mathrm{OL}}=421.85, \mathrm{M}_{\mathrm{N}-\mathrm{OL}}=179.46 ; \mathrm{F}=18.914, p<0.001\right)$. There was a significant difference in the number of comments received by the two groups $\left(\mathrm{M}_{\mathrm{OL}}=692.90, \mathrm{M}_{\mathrm{N}-\mathrm{OL}}=221.63\right)(\mathrm{F}=44.796, p<0.001)$.

There was also a significant difference in the number of likes obtained by the two groups $\left(\mathrm{M}_{\mathrm{OL}}=1610.20, \mathrm{M}_{\mathrm{N}-\mathrm{OL}}=498.79 ; \mathrm{F}=28.224, p<0.001\right)$. The above results show 
thatin order to become an opinion leader in a consumer advice network, it is essential to actively contribute content and participate in interaction.

\section{Conclusions}

This paper investigates the factors influencing network relationship-building through the online behavioral activities and network structure data of 1356 hotel sleep testers in a Chinese travel online content community (http: / / tips.qunar.com/, accessed on 2 May 2005). Through a study of network relationship-building and a comparison of opinion leader and non-opinion leader data, we obtained several important conclusions.

(1) In consumer advice networks, members' online behavioral activities, including content contributions, social interactions, and help provided to other members, are key factors in attracting network members to build network relationships. Active members are highly likely to become influencers or opinion leaders, contributing to the sustainability of the network. These findings are consistent with previous results in traditional social networks. For example, in traditional social networks, influential nodes are activeness in the group and the most content contribution [93,94].

(2) Network structures of members, such as in-degree, structural equivalence, and homophily, also play very important roles in the establishment of network relationships. However, reciprocity, which is more influential in acquaintance networks, does not play a significant role in consumer advisory networks. This is the main difference between acquaintance social networks and para-social relationship networks found so far. Reciprocity is prevalent in strongly linked relationship networks and has a significant impact on the stability and sustainability of social networks [95-97].

(3) An analysis of variance (ANOVA) was conducted on the network structure and on the behavioral activity data of opinion leaders and non-opinion leaders. The results further support the above findings that the key factors for network members to become opinion leaders include in-degree, content contributions, social interactions, and helpfulness.

\section{Discussion and Future Directions}

\subsection{Theoretical Contribution}

First, this paper enriches the study of social networks by dividing them into two categories: traditional social networks and consumer advice networks. The most essential difference between the two is that the network relationship in social networks is a socially embedded relationship that reflects people's connection in real life and thus is a strong relationship; however, the relationship in consumer advice networks is a virtual relationship that exists independently of real life and thus is a weak relationship. Moreover, in social networks, network nodes establish relationships mainly for social interaction and thus for emotional support, while in consumer advice networks, network relationships are established mainly for information acquisition.

Second, this study also explores the construction of relationships in consumer advice networks, showing the mechanism of network formation. For consumer advice networks, the role of network relationships is information acquisition, thus network members are most likely to establish relationships with those who can provide rich information and thus they realize the value of the relationship.

Last but not least, this study also deepens the understanding of behavioral activities. Previous research on behavioral activities has focused more on their impact on consumers' purchase decisions. In contrast, our study shows that behavioral activities (e.g., contributing content, interacting with information, and liking) play an equal role in the establishment of online relationships and in the formation of opinion leaders.

\subsection{Suggestions for the Sustainable Development of CANs}

The Internet has moved from Web 1.0 to 2.0 and now into the mobile Internet era. The SoLo Moization of consumer behavior, i.e., social, location, and mobile elements, drives 
the socialization of consumer decision-making, with $70 \%$ of consumers relying on e-WOM as a source of information. For this reason, many companies are shifting from traditional advertising models to digital content marketing models, as well as social media influencer marketing models. Therefore, companies need to gain insight into the evolution mechanism of consumer advice networks as well as into the opinion leadership formation mechanism.

Firstly, it is possible to establish trusting relationships with opinion leaders early on. This requires companies to identify potential opinion leaders through social network analysis methods as early as possible and to establish both interaction and trust relationships with them in advance.

Second, companies can cultivate their own opinion leaders from the consumers' perspective. Opinion leaders have their own formation mechanisms and companies can fully apply the formation law revealed in this study to cultivate their own opinion leaders.

Again, companies can provide appropriate information according to the needs of opinion leaders and use their influence to serve their marketing activities. As an important information source in consumer advice networks, the information released by opinion leaders has an important influence on other network members.

Finally, companies can use social media to establish their own consumer advice networks. The formation of an opinion leader is essentially the establishing of a community or a group of people with common interests that establish their own community around certain influential opinion leaders. Companies can leverage the unique needs and behavior patterns of these members to establish communities that are attached to their own brands. Some successful examples include Xiaomi's fan community built by Xiaomi Mobile Corporation and WeChat fan groups built by NIO Automotive Corporation.

\subsection{Future Directions}

Consumer advice networks emerged in the context of SMI marketing and online community marketing. The sustainability of consumer advice communities still faces many issues. For example, unlike the strong social relationships constructed between acquaintance social networks, consumer advice networks are mainly para-social relationships constructed between strangers [98]. Additionally, exploring the process of relationship construction between influencers and consumers by introducing communication theories, such as para-social interaction and para-social relationships, is an important research question [99-101]. The issue of trust between consumers and influencers is another important research direction in consumer advice networks [19,31,102]. Consumer identification with communities $[103,104]$, mechanisms of cooperation between companies and opinion leaders in the community, and companies' management strategies for the community are also urgent future research questions [105].These are the key issues that affect the sustainability of consumer advice communities.

Author Contributions: Conceptualization, L.W.; data curation, J.L. and X.L.; formal analysis, J.L.; funding acquisition, L.W. and J.Q.; investigation, D.K.; project administration, L.W.; software, D.K. and X.L.; supervision, J.Q.; visualization, J.L.; writing—original draft preparation, L.W.; writing—review and editing, D.K. All authors have read and agreed to the published version of the manuscript.

Funding: This work was supported by the Philosophy and Social Science Foundation of Shanghai (grant number:2020EGL017); by the National Natural Science Foundation of China (grant number: 71601005 and 72042004); and by Digital Transformation in China and Germany: Strategies, Structures and Solutions for Aging Societies (grant number: GZ 1570).

Institutional Review Board Statement: Not applicable.

Informed Consent Statement: Informed consent was obtained from all subjects involved in the study.

Data Availability Statement: Not applicable.

Conflicts of Interest: The authors declare no conflict of interest. 


\section{References}

1. Bowden, J.; Mirzaei, A. Consumer engagement within retail communication channels: An examination of online brand communities and digital content marketing initiatives. Eur. J. Mark. 2021, 55, 1411-1439. [CrossRef]

2. Ho, C.W.; Wang, Y.B. Does Social Media Marketing and Brand Community Play the Role in Building a Sustainable Digital Business Strategy? Sustainability 2020, 12, 6417. [CrossRef]

3. Yasin, M.; Porcu, L.; Liébana-Cabanillas, F. The effect of brand experience on customers' engagement behavior within the context of online Brand communities: The impact on intention to forward online Company-Generated content. Sustainability 2019, 11, 4649. [CrossRef]

4. Wibowo, A.; Chen, S.C.; Wiangin, U.; Ma, Y.; Ruangkanjanases, A. Customer behavior as an outcome of social media marketing: The role of social media marketing activity and customer experience. Sustainability 2021, 13, 189. [CrossRef]

5. Myers, J.H.; Robertson, T.S. Dimensions of opinion leadership. J. Mark. Res. 1972, 9, 41-46. [CrossRef]

6. Borgatti, S.P.; Mehra, A.; Brass, D.J.; Labianca, G. Network analysis in the social sciences. Science 2009, 323, 892-895. [CrossRef]

7. Childers, T.L. Assessment of the psychometric properties of an opinion leadership scale. J. Mark. Res. 1986, 23, 184-188. [CrossRef]

8. Xiao, L.; Guo, F.; Yu, F.; Liu, S. The effects of online shopping context cues on consumers' purchase intention for cross-border E-Commerce sustainability. Sustainability 2019, 11, 2777. [CrossRef]

9. Chevalier, J.A.; Mayzlin, D. The Effect of Word of Mouth on Sales: Online Book Reviews. J. Mark. Res. 2006, 43, 345-354. [CrossRef]

10. Ludwig, S.; De Ruyter, K.; Friedman, M. More Than Words: The Influence of Affective Content and Linguistic Style Matches in Online Reviews on Conversion Rates. J. Mark. 2013, 77, 87-103. [CrossRef]

11. Iyengar, R.; Van den Bulte, C.; Valente, T.W. Opinion Leadership and Social Contagion in New Product Diffusion. Mark. Sci. 2011, 30, 195-212. [CrossRef]

12. Lu, Y.; Jerath, K.; Singh, P.V. The Emergence of Opinion Leaders in a Networked Online Community: A Dyadic Model with Time Dynamics and a Heuristic for Fast Estimation. Manag. Sci. 2013, 59, 1783-1799. [CrossRef]

13. Shriver, S.K.; Nair, H.S.; Hofstetter, R. Social Ties and User-Generated Content: Evidence from an Online Social Network. Mark. Sci. 2013, 59, 1425-1443. [CrossRef]

14. Goes, P.B.; Lin, M.; Au-Yeung, C. "Popularity effect" in user-generated content: Evidence from online product reviews. Inf. Syst. Res. 2014, 25, 222-238. [CrossRef]

15. Phua, J.; Jin, S.V.; Kim, J.J. Gratifications of using Face-book, Twitter, Instagram, or Snapchat to follow brands: The moderating effect of social comparison, trust, tie strength, and network homophily on brand identification, brand engagement, brand commitment, and membership intention. Telemat. Inform. 2017, 34, 412-424. [CrossRef]

16. Kay, S.; Mulcahy, R.; Parkinson, J. When less is more: The impact of macro and micro social media influencers' disclosure. J. Mark. Manag. 2020, 36, 248-278. [CrossRef]

17. Berne-Manero, C.; Marzo-Navarro, M. Exploring how influencer and relationship marketing serve corporate sustainability. Sustainability 2020, 12, 4392. [CrossRef]

18. Torres, P.; Augusto, M.; Matos, M. Antecedents and outcomes of digital influencer endorsement: An exploratory study. Psychol. Mark. 2019, 36, 1267-1276. [CrossRef]

19. Kim, D.Y.; Kim, H.Y. Trust me, trust me not: A nuanced view of influencer marketing on social media. J. Bus. Res. 2021, 134, 223-232. [CrossRef]

20. Ki, C.W.C.; Kim, Y.K. The mechanism by which social media influencers persuade consumers: The role of consumers' desire to mimic. Psychol. Mark. 2019, 36, 905-922. [CrossRef]

21. Ki, C.W.C.; Cuevas, L.M.; Chong, S.M.; Lim, H. Influencer marketing: Social media influencers as human brands attaching to followers and yielding positive marketing results by fulfilling needs. J. Retail. Consum. Serv. 2020, 55, 102133. [CrossRef]

22. Casaló, L.V.; Flavián, C.; Ibáñez-Sánchez, S. Influencers on Instagram: Antecedents and consequences of opinion leadership. J. Bus. Res. 2020, 117, 510-519. [CrossRef]

23. Cooley, D.; Parks-Yancy, R. The effect of social media on perceived information credibility and decision making. J. Internet Commer. 2019, 18, 249-269. [CrossRef]

24. Lin, H.C.; Bruning, P.F.; Swarna, H. Using online opinion leaders to promote the hedonic and utilitarian value of products and services. Bus. Horiz. 2018, 61, 431-442. [CrossRef]

25. De Veirman, M.; Cauberghe, V.; Hudders, L. Marketing through instagram influencers: The impact of number of followers and product divergence on brand attitude. Int. J. Advert. 2017, 36, 798-828. [CrossRef]

26. Shareef, M.A.; Mukerji, B.; Dwivedi, Y.K.; Rana, N.P.; Islam, R. Social media marketing: Comparative effect of advertisement sources. J. Retail. Consum. Serv. 2019, 46, 58-69. [CrossRef]

27. Martensen, A.; Brockenhuus-Schack, S.; Zahid, A.L. How citizen influencers persuade their followers. J. Fash. Mark. Manag. Int. J. 2018, 22, 335-353. [CrossRef]

28. Mcquarrie, E.F.; Miller, J.; Phillips, B.J. The megaphone effect: Taste and audience in fashion blogging. J. Consum. Res. 2012, 40, 136-158. [CrossRef]

29. Audrezet, A.; De Kerviler, G.; Moulard, J.G. Authenticity under threat: When social media influencers need to go beyond self-presentation. J. Bus. Res. 2020, 117, 557-569. [CrossRef] 
30. Feijoo, B.; Sádaba, C. The Relationship of Chilean Minors with Brands and Influencers on Social Networks. Sustainability 2021, 13, 2822. [CrossRef]

31. Lou, C.; Yuan, S. Influencer marketing: How message value and credibility affect consumer trust of branded content on social media. J. Interact. Advert. 2019, 19, 58-73. [CrossRef]

32. Stubb, C.; Colliander, J. "This is not sponsored content"-the effects of impartiality disclosure and e-commerce landing pages on consumer responses to social media influencer posts. Comput. Hum. Behav. 2019, 98, 210-222. [CrossRef]

33. Gannon, V.; Prothero, A. Beauty blogger selfies as authenticating practices. Eur. J. Mark. 2016, 50, 1858-1878. [CrossRef]

34. Liu, J.; Zhang, Z.; Qi, J.; Wu, H.; Chen, M. Understanding the impact of opinion leaders' characteristics on online group knowledge-sharing engagement from in-group and out-group perspectives: Evidence from a Chinese online knowledge-sharing community. Sustainability 2019, 11, 4461. [CrossRef]

35. Tsang, A.S.; Zhou, N. Newsgroup participants as opinion leaders and seekers in online and offline communication environments. J. Bus. Res. 2005, 58, 1186-1193. [CrossRef]

36. Shoham, A.; Ruvio, A. Opinion leaders and followers: A replication and extension. Psychol. Mark. 2008, 25, 280-297. [CrossRef]

37. Turcotte, J.; York, C.; Irving, J.; Scholl, R.M.; Pingree, R.J. News recommendations from social media opinion leaders: Effects on media trust and information seeking. J. Comput. Commun. 2015, 20, 520-535. [CrossRef]

38. Lyons, B.; Henderson, K. Opinion leadership in a computer-mediated environment. J. Consum. Behav. 2005, 4, 319-329. [CrossRef]

39. Ouyang, F.; Scharber, C. The influences of an experienced instructor's discussion design and facilitation on an online learning community development: A social network analysis study. Internet High. Educ. 2017, 35, 34-47. [CrossRef]

40. Zhang, S.; Liu, Q.; Chen, W.; Wang, Q.; Huang, Z. Interactive networks and social knowledge construction behavioral patterns in primary school teachers' online collaborative learning activities. Comput. Educ. 2017, 27, R713-R715. [CrossRef]

41. Valente, T.W.; Pumpuang, P. Identifying opinion leaders to promote behavior change. Health Educ. Behav. 2007, 34, 881-896. [CrossRef]

42. Li, F.; Du, T.C. Who is talking? An ontology-based opinion leader identification framework for word-of-mouth marketing in online social blogs. Decis. Support Syst. 2001, 51, 190-197. [CrossRef]

43. Awad, N.F.; Ragowsky, A. Establishing trust in electronic commerce through online word of mouth: An examination across genders. J. Manag. Inf. Syst. 2008, 24, 101-121. [CrossRef]

44. Bala, V.; Goyal, S. A Noncooperative Model of Network Formation. Econometrica 2000, 68, 1181-1229. [CrossRef]

45. Goyal, S.; Vega-Redondo, F. Network Formation and Social Coordination. Games Econ. Behav. 2005, 50, 178-207. [CrossRef]

46. Schmidt, F.L. Implications of a measurement problem for expectancy theory research. Organ. Behav. Hum. Perf. 1973, 10, 243-251. [CrossRef]

47. Zhang, J.; Zhu, Q.; Wang, Y. Social capital on consumer knowledge-sharing in virtual brand communities: The mediating effect of pan-family consciousness. Sustainability 2019, 11, 339. [CrossRef]

48. Wasko, M.M.L.; Faraj, S. Why Should I Share? Examining Social Capital and Knowledge Contribution in Electronic Networks of Practice. MIS Q. 2005, 29, 35-57. [CrossRef]

49. Yin, X.; Wang, H.; Xia, Q.; Gu, Q. How social interaction affects purchase intention in social commerce: A cultural perspective. Sustainability 2019, 11, 2423. [CrossRef]

50. Blazevic, V.; Wiertz, C.; Cotte, J.; de Ruyter, K.; Keeling, D.I. GOSIP in cyberspace: Conceptualization and scale development for general online social interaction propensity. J. Interact. Mark. 2014, 28, 87-100. [CrossRef]

51. Schlosser, A.E. Posting versus lurking: Communicating in a multiple audience context. J. Consum. Res. 2005, 32, 260-265. [CrossRef]

52. Wiertz, C.; de Ruyter, K. Beyond the call of duty: Why customers contribute to firm-hosted commercial online communities. Organ. Stud. 2007, 28, 347-376. [CrossRef]

53. Dessart, L. Social media engagement: A model of antecedents and relational outcomes. J. Mark. Manag. 2017, 33, 375-399. [CrossRef]

54. Casaló, L.V.; Flavián, C.; Guinalíu, M. Antecedents and consequences of consumer participation in on-line communities: The case of the travel sector. Int. J. Electron. Commer. 2010, 15, 137-167. [CrossRef]

55. Akram, U.; Hui, P.; Khan, M.K.; Yan, C.; Akram, Z. Factors affecting online impulse buying: Evidence from Chinese social commerce environment. Sustainability 2018, 10, 352. [CrossRef]

56. Yin, D.; Bond, S.D.; Zhang, H. Anxious or angry? Effects of discrete emotions on the perceived helpfulness of online reviews. MIS Q. 2014, 38, 539-560. [CrossRef]

57. Singh, J.P.; Irani, S.; Rana, N.P.; Dwivedi, Y.K.; Saumya, S.; Roy, P.K. Predicting the "helpfulness" of online consumer reviews. J. Bus. Res. 2017, 70, 346-355. [CrossRef]

58. Cao, Q.; Duan, W.; Gan, Q. Exploring determinants of voting for the "helpfulness" of online user reviews: A text mining approach. Decis. Support Syst. 2011, 50, 511-521. [CrossRef]

59. Schindler, R.M.; Bickart, B. Perceived helpfulness of online consumer reviews: The role of message content and style. J. Consum. Behav. 2012, 11, 234-243. [CrossRef]

60. Huang, A.H.; Chen, K.; Yen, D.C.; Tran, T.P. A study of factors that contribute to online review helpfulness. Comput. Hum. Behav. 2015, 48, 17-27. [CrossRef] 
61. Qazi, A.; Syed, K.B.S.; Raj, R.G.; Cambria, E.; Tahir, M.; Alghazzawi, D. A concept-level approach to the analysis of online review helpfulness. Comput. Hum. Behav. 2016, 58, 75-81. [CrossRef]

62. Leal, G.P.A.; Hor-Meyll, L.F.; de Paula Pessôa, L.A.G. Influence of virtual communities in purchasing decisions: The participants' perspective. J. Bus. Res. 2014, 67, 882-890. [CrossRef]

63. Djafarova, E.; Rushworth, C. Exploring the credibility of online celebrities' Instagram profiles in influencing the purchase decisions of young female users. Comput. Hum. Behav. 2017, 68, 1-7. [CrossRef]

64. Huffaker, D. Dimensions of leadership and social influence in online communities. Hum. Commun. Res. 2010, 36, 593-617. [CrossRef]

65. Barabási, A.L. Network Science: Luck or Reason. Nature 2012, 489, 507-508. [CrossRef] [PubMed]

66. Goeree, J.K.; Riedl, A.; Ule, A. In Search of Stars: Network Formation among Heterogeneous Agents. Games Econ. Behav. 2009, 67, 445-466. [CrossRef]

67. Yan, Q.; Wu, L.R.; Zheng, L. Social network based micro-blog user behavior analysis. Phys. A Stat. Mech. Appl. 2013, 392, 1712-1723. [CrossRef]

68. Gilly, M.C.; Graham, J.L.; Wolfinbarger, M.F.; Yale, L.J. A dyadic study of interpersonal information search. J. Acad. Mark. Sci. 1998, 26, 83-100. [CrossRef]

69. Wang, X.; Yu, C.; Wei, Y. Social media peer communication and impacts on purchase intentions: A consumer socialization framework. J. Interact. Mark. 2012, 26, 198-208. [CrossRef]

70. Gerard, H.B.; Greenbaum, C.W. Attitudes toward an agent of uncertainty reduction. J. Personal. 1962, 30, 485-495. [CrossRef]

71. McPherson, M.; Smith-Lovin, L.; Cook, J.M. Birds of a feather: Homophily in social networks. Annu. Rev. Soc. 2001, 27, 415-444. [CrossRef]

72. Kossinets, G.; Watts, D.J. Origins of homophily in an evolving social network. Am. J. Sociol. 2009, 115, 405-450. [CrossRef]

73. Centola, D. An experimental study of homophily in the adoption of health behavior. Science 2011, 334, 1269-1272. [CrossRef]

74. Ma, L.; Krishnan, R.; Montgomery, A.L. Latent homophily or social influence? An empirical analysis of purchase within a social network. Manag. Sci. 2015, 61, 454-473. [CrossRef]

75. Burt, R.S. Social contagion and innovation: Cohesion versus structural equivalence. Am. J. Sociol. 1987, 92, 1287-1335. [CrossRef]

76. Burt, R.S. The network structure of social capital. Res. Organ. Behav. 2000, 22, 345-423. [CrossRef]

77. Leider, S.; Möbius, M.M.; Rosenblat, T.; Do, Q.A. Directed altruism and enforced reciprocity in social networks. Q. J. Econ. 2009, 124, 1815-1851. [CrossRef]

78. Dakin, R.; Ryder, T.B. Reciprocity and behavioral heterogeneity govern the stability of social networks. Proc. Natl. Acad. Sci. USA 2020, 117, 2993-2999. [CrossRef] [PubMed]

79. Adler, P.S.; Kwon, S.W. Social capital: Prospects for a new concept. Acad. Manag. Rev. 2002, 27, 17-40. [CrossRef]

80. Constant, D.; Kiesler, S.; Sproull, L. What's mine is ours, or is it? A study of attitudes about information sharing. Inf. Syst. Res. 1994, 5, 400-421. [CrossRef]

81. Huber, G.P. Transfer of knowledge in knowledge management systems: Unexplored issues and suggested studies. Eur. J. Inf. Syst. 2001, 10, 72-79. [CrossRef]

82. Xiong, Y.; Cheng, Z.C.; Liang, E.H.; Wu, Y.B. Accumulation mechanism of opinion leaders' social interaction ties in virtual communities: Empirical evidence from China. Comput. Hum. Behav. 2018, 82, 81-93. [CrossRef]

83. Qunar Travel. Available online: https:/ / www.qunar.com/ (accessed on 2 May 2005).

84. Sinha, R.K.; Chandrashekaran, M. A split hazard model for analyzing the diffusion of innovations. J. Mark. Res. 1992, 29, 116-127. [CrossRef]

85. Seetharaman, P.B.; Chintagunta, P.K. The proportional hazard model for purchase timing: A comparison of alternative specifications. J. Bus. Econ. Stat. 2003, 21, 368-382. [CrossRef]

86. Topirceanu, A.; Udrescu, M.; Marculescu, R. Weighted betweenness preferential attachment: A new mechanism explaining social network formation and evolution. Sci. Rep. 2018, 8, 10871. [CrossRef]

87. Simpson, C.R. On the structural equivalence of coresidents and the measurement of village social structure. Soc. Netw. 2020. Available online: https:/ / doi.org/10.1016/j.socnet.2020.02.010 (accessed on 19 June 2020). [CrossRef]

88. Huang, Y.; Shen, C.; Contractor, N.S. Distance matters: Exploring proximity and homophily in virtual world networks. Decis. Support Syst. 2013, 55, 969-977. [CrossRef]

89. Collet, F.; Philippe, D. From hot cakes to cold feet: A contingent perspective on the relationship between market uncertainty and status homophily in the formation of alliances. J. Manag. Stud. 2014, 51, 406-432. [CrossRef]

90. Ertug, G.; Gargiulo, M.; Galunic, C.; Zou, T. Homophily and individual performance. Organ. Sci. 2018, 29, 912-930. [CrossRef]

91. Trusov, M.; Bodapati, A.V.; Bucklin, R.E. Determining influential users in internet social networks. J. Mark. Res. 2010, 47, 643-658. [CrossRef]

92. Goldenberg, J.; Han, S.; Lehmann, D.R.; Hong, J.W. The role of hubs in the adoption process. J. Mark. 2009, 73, 63-92. [CrossRef]

93. Aral, S.; Walker, D. Identifying influential and susceptible members of social networks. Science 2012, 337, 337-341. [CrossRef] [PubMed]

94. Li, Y.M.; Lin, C.H.; Lai, C.Y. Identifying influential reviewers for word-of-mouth marketing. Electron. Commer. Res. Appl. 2010, 9 , 294-304. [CrossRef] 
95. Surma, J. Social exchange in online social networks. The reciprocity phenomenon on Facebook. Comput. Commun. 2016, 73, 342-346. [CrossRef]

96. Block, P. Reciprocity, transitivity, and the mysterious three-cycle. Soc. Netw. 2015, 40, 163-173. [CrossRef]

97. Schweitzer, F.; Mavrodiev, P.; Seufert, A.M.; Garcia, D. Modeling user reputation in online social networks: The role of costs, benefits, and reciprocity. Entropy 2020, 22, 1073. [CrossRef]

98. Brown, W.J. Examining four processes of audience involvement with media personae: Transportation, parasocial interaction, identification, and worship. Commun. Theory 2015, 25, 259-283. [CrossRef]

99. Aw, E.C.X.; Chuah, S.H.W. "Stop the unattainable ideal for an ordinary me!" fostering parasocial relationships with social media influencers: The role of self-discrepancy. J. Bus. Res. 2021, 132, 146-157. [CrossRef]

100. Sokolova, K.; Perez, C. You follow fitness influencers on YouTube. But do you actually exercise? How parasocial relationships, and watching fitness influencers, relate to intentions to exercise. J. Retail. Consum. Serv. 2021, 58, 102276. [CrossRef]

101. Reinikainen, H.; Munnukka, J.; Maity, D.; Luoma-aho, V. 'You really are a great big sister'-parasocial relationships, credibility, and the moderating role of audience comments in influencer marketing. J. Mark. Manag. 2020, 36, 279-298. [CrossRef]

102. Breves, P.; Amrehn, J.; Heidenreich, A.; Liebers, N.; Schramm, H. Blind trust? The importance and interplay of parasocial relationships and advertising disclosures in explaining influencers' persuasive effects on their followers. Int. J. Advert. 2021. Available online: https:/ / doi.org/10.1080/02650487.2021.1881237 (accessed on 17 February 2021). [CrossRef]

103. Shan, Y.; Chen, K.J.; Lin, J.S. When social media influencers endorse brands: The effects of self-influencer congruence, parasocial identification, and perceived endorser motive. Int. J. Advert. 2020, 39, 590-610. [CrossRef]

104. Lim, J.S.; Choe, M.J.; Zhang, J.; Noh, G.Y. The role of wishful identification, emotional engagement, and para-social relationships in repeated viewing of live-streaming games: A social cognitive theory perspective. Comput. Hum. Behav. 2020, $108,106327$. [CrossRef]

105. Ngo, T.; Lohmann, G.; Hales, R. Collaborative marketing for the sustainable development of community-based tourism enterprises: Voices from the field. J. Sustain. Tour. 2018, 26, 1325-1343. [CrossRef] 